\title{
Lugu ja sündmus jutu-uurimises: situatsioonianalüüsist kontekstianalüüsini ${ }^{1}$
}

\author{
Pühendatud Aino Laagusele (1944-2004)
}

Tiiu Jaago

\begin{abstract}
Teesid. Artiklis käsitletakse rahvajutu-uurimise üht arenguliini: võttes fookusse Aino Laaguse 1970. aastate alguses väljatöötatud situatsioonianalüüsi, tutvustatakse strukturalismi ja konstruktivismi raame tõsielujutustuste uurimisel viimase nelja aastakümne jooksul. Jättes hetkel kõrvale nii teema- ja motiivide leviku kui ka žanrikesksed uurimismeetodid, esitatakse kaks küsimust: 1) mida kujutab endast situatsioonianalüüs kui meetod ja 2) kuidas see rakenduks tänapäevases kontekstikeskses jutu-uurimises. Eelkõige näidatakse seoseid situatsioonianalüüsi ja eluloo- ning pärimusliku (suulise) ajaloo uurimise vahel.
\end{abstract}

Märksõnad: jutu-uurimismeetodid, pärimuslik ajalugu, situatsioonianalüüs

1960. aastate lõpus, 1970. aastate alguses töötas Aino Laagus eesti metshaldjatekstide põhjal välja situatsioonianalüüsiks nimetatud meetodi, mis teoreetiliselt rajanes strukturalismile. ${ }^{2}$ Vajadus sellise analüüsi järele tulenes Eesti Rahvaluule Arhiivis (nõukogudeaegse nimetusega kirjandusmuuseumi rahvaluuleosakonnas) talletatavate haldjatekstide tekstiomaduste erinevustest: žanriliselt olid need peamiselt muistendid ja usundilised teated, mis võisid pakkuda nii pikemaid olukirjeldusi kui ka elamusmeenutusi, nii lühiteateid kui ka vihjeid. Uurija ette kerkis küsimus, kuidas analüüsida metshaldjateadmust sisaldavaid, kuid erinevate rõhuasetuste, erineva pikkuse ja stiiliga tekste kui ühtset tekstikorpust. Üldisemalt kutsus sedalaadi analüüsimeetodi esile tolle ajajärgu teadusmõte, mille raames otsiti tekstide täppisanalüüsi võimalusi ja viise ning kus üheks oluliseks märksõnaks kujunes teksti struktuur. ${ }^{3}$

\section{Situatsioonianalüüs}

Situatsioonianalüüsis jaotatakse tekst struktuurseteks osadeks vastavalt järgnevale skeemile: esmalt tegevussituatsioon: jutustatav tegevus, tegevusaeg, -koht (ruum), kogeja, haldjas, atribuudid (nt haldja kuju tunnused, olu- 
korras kaasa mängivad esemed jms), tekstiväline komponent (nt tekstis sõnastamata käitumisreeglid, mida pärimusrühm tundis ja mille vastu eksimine kutsus pärimuse kohaselt esile teatavad tagajärjed); teiseks teatamissituatsioon: teatamisaeg, ja -koht, teataja suhtumine juhtumisse, tegevussituatsiooni teadmine ja edasiandmine, kõnelemise eesmärk. Selline kahene jaotus - tegevussituatsioon ja teatamissituatsioon - viitab vajadusele eristada tekstianalüüsis jutuväline sündmus (mis saab aluseks jutusündmusele) jutustamisest kui omaette sündmusest (mida kujundab jutustamisolukord, sh jutustaja ja kuulajate või vestluspartnerite osa jutuvälisest tegelikkusest kõnelemisel). Jutustamisolukorra lisamine analüüsi muudab situatsioonianalüüsimeetodi lähedaseks hilisematele (1990. aastate) kontekstikesksetele jutuanalüüsi meetoditele. Kuigi ka need meetodid rakenduvad tõsielusündmusjuttudele, ei keskenduta situatsioonianalüüsist erinevalt enam kirjas fikseeritud suhteliselt lühikese teksti omadustele (kuna üldjuhul analüüsitakse tunduvalt pikemaid tekste ja sama loo arenguid erinevate esituste protsessis). Ühtlasi pühendutakse kontekstikesksete meetodite puhul enam tekstide tähendustele nii jutustajate, kuulajate kui ka uurijate seisukohalt (kuna huvikese asetub tekstiomadustelt endilt tekstide sotsiaalsele rollile).

Põhimõtteliselt võib situatsioonianalüüsi teatamissituatsioonis eristada kahte tasandit: esmalt juhtunu ja/või sellest saadud kogemuse jutustamine pärimusrühma raames (see on protsess, kus individuaalselt kogetud fakt seotakse sotsiaalse kogemusega) ja teiseks juba järgnevad jutustamised, sh jutustamine rahvaluulekogujale. Viimast nimetab Aino Laagus teatamissituatsiooni piirijuhuks, kuid just nii sündinud tekste Aino Laagus analüüsibki.

Analüüs rajaneb arusaamal, et uskumus ja vastavad teadmised on pärimuses üldiselt olemas. Jutustamisel ilmnevad selle (pärimusliku üldteadmise) ja reaalsete sündmuste tõlgendamise valitud tahud. ${ }^{4}$ Situatsioonianalüüsi rakendas Aino Laagus usundiliste muistendite ja teadete analüüsiks, kus huvikeskmesse ei asetanud ta mitte usundilist kujutelma, tegelast vms andmestikku, vaid jutustuse (teksti) - selle ülesehituse, stiili, tekstides esitatava andmesti$\mathrm{ku}$ tervikuna. Tegemist on tõsielujutustustega $\mathrm{a}^{\mathbf{5}}$, mis tekstidena on vormilt küllalt muutlikud, kuna Aino Laaguse sõnutsi üks ja seesama uskumus võib tekstis avalduda mitmeti. Need on tekstid, mis modelleerivad tegelikke või mõeldavaid situatsioone. ${ }^{6}$ Metshaldjatekstides sisalduv maailmapilt ei ole ainult teoreetiline, vaid tekstid sisaldavad ka teavet ühiskonnas kinnistunud käitumisnormidest, mida inimene pidi teadma, tundma ja arvestama - tekstivälise tegelikkuse ja tekstis kujutava tegelikkuse vahel on dünaamiline seos. ${ }^{7}$ 


\section{Teooria koht folkloristlikus uurimuses}

Situatsioonianalüüsi üldteoreetiline plaan, millele Aino Laagus otseselt küll ei viita, assotsieerub konstruktivismiideedega: kõneldakse tekstide osast maailma mõistmis- ja mõtestamisprotsessis ning seega ka tekstide ja tõsielu vastastikustest (mitte ühesuunalistest) mõjutusseostest. ${ }^{8}$

Eesti folkloristika on oma loomult materjalikeskne, mistõttu uurijad enamasti ei määratlegi oma tööd suurte teooriate kaudu: folkloristlikes töödes ei leia üldiselt üheseid sedastusi, et tegemist on feministliku, konstruktivistliku vms uurimusega. ${ }^{9}$ Näib, et uute mõttemallidega eelistatakse seostuda vaikimisi: kasutatakse ja kujundatakse folkloristika traditsioonilisi või sellest tuletatud termineid (nt 'tänapäeva muistend', mis oma loomult on oksüümoron, viidates teineteist välistavatele aegadele - tänapäevane ja muistne; 'pärimuspilt' kui analüüsitava teksti folkloorne kontekst), üldteoreetilist raami puudutav teave asetub materjali analüüsi taha. Näiteks võib tuua tänapäevast tõlgenduslikku uurimisviisi esindava Mare Kalda arutluse artiklis, kus ta analüüsib üht 17. sajandi lõpu üleloomulikku elamust kajastavat isikulugu, mis on avaldatud peaaegu sada aastat hiljem. ${ }^{10}$ 'Pärimuspildi konteksti' (Mare Kalda sõnastuses) kui üht kontekstikeskset uurimisviisi kasutades viitab ta folkloristist tõlgendajat varitsevale ahvatlusele:

2006. aasta uurija tahaks muidugi määrata, kas Torsten Grön kohtas vaimu või kodukäijat, painajat või kuradi kehastust. Kuid just sedaliiki üldistuste eest hoiatab õigusega David Hufford, kes on seisukohal, et paikapidav uskumusekirjeldus peab leidma heakskiidu selle poolt, kellele ta omistati (Hufford 1995: 58). Uurija ei saa meelevaldselt liigitada uskumusolendit, keda kogeti. [---] Ilmuda võisid inglid ja Jeesus ning kurat mitmesugusel kujul (Beyer 2000: 75). Kodukäija tuleb kõne alla kas 17. sajandi lõpust (Beyer 2000: 75) või 18. sajandi algusest (Bennett 1999: 146, 162-172) ja kummitusjuttudeks hakati lugusid liigitama veel hiljem (Beyer 2000: 75). Torsten Gröni historiograaf ei vihja kuidagi kodukäijale, seega ei tõesta lugu, et 1687. aastal oleks niisugust halba ilmutust peetud kodukäijaks (Kalda 2006: 105).

Tsitaadis viidatakse tõlgenduses peituvatele problemaatilisusele - tõlgendus pole lihtsalt tõlgendus, vaid see luuakse teatud ajaloolises või pärimuslikus vms kontekstis. ${ }^{11}$ See lähenemisviis seostub arusaamaga pärimusest ja selle teaduslikust tõlgendusest kui (sotsiaalsest) konstruktsioonist, kuid artikli vältel nende üldteoreetiliste (filosoofiliste) mõistetega ei tegelda, kuna uurija tähelepanukeskmes on tõepoolest konkreetne tekst ja sellega seonduv tekstiteave. 


\section{Situatsioonianalüüsi näide}

Milliseid küsimusi esitatakse situatsioonianalüüsi, milliseid kontekstianalüüsi puhul? Alljärgnevalt toon sellekohase näite. Valisin ühe haldjateksti (siiski mitte metshaldjast, vaid kääpast ${ }^{12}$ ), mis on salvestatud 1990. aastal rahvaluule kogumispraktikal Läänemaale. Esitlen seda esmalt Aino Laaguse situatsioonianalüüsi kasutades, kuid viitan ka hilisematele tõsielujututuste uurimisele omastele mõistetele nagu 'elamuslugu', 'kogemuslugu'. ${ }^{13}$

Jutustaja arutleb uskumisküsimuste üle (ma ei tea, kas teie usute, aga ma räägin tõsiselt; vaata, vanad inimesed uskusid niisuguseid asju, mina ei uskunud). Ühtlasi on siin nähtaval sündmuse erinevad tasandid: ta esitab oma eksimisloo kui jutusündmuse (tegevussituatsioon), eksimisest vanaemale kõnelemise kui uue sündmuse (teatamissituatsioon), ja ühtlasi on omaette sündmuseks, teatamissituatsiooni üheks ilminguks, ka selle loo jutustamine rahvaluuleüliõpilastele1990. aastal (teatamissituatsiooni piirijuhtum).

Tekstis sisaldub jutustaja elamuslugu (see, mis jutustaja öeldu kohaselt tõesti juhtus ja millise elamuse see talle tekitas) ning nii pärimusrühma kollektiivne kui ka jutustaja individuaalne kogemuslugu (mida niisugustest sündmustest ja neist tekkinud elamustest järeldati ja mida ta ise sellest arvab). Jutt põimib elamus- ja kogemusloo ühitamise abil argielulisuse maailmapildilisusega. Sellele lisandub viide tõsielulisusele (jutuvälisele tegelikkusele), sest jutustaja veenab kuulajaid: see lugu on tõesti sündinud ( $m a$ räägin tõsiselt; ta osutab täpselt tegevusajale ja kohale, mis on loogiliselt reaalsed, lisaks pakub ta selle paiga lühiajaloo-palju-palju aastaid tagasi olnud seal...).

Seda ma räägin. Ma ei tea, kas te usute nü̈̈d mu juttu või ei usu. Aga ma räägin tõsiselt. Seal keskpaiku, kus need väljakaevamised on, seal on kääpaaugud. ${ }^{14}$ Minu vanaema rääkis, et palju-palju aastaid tagasi olnud seal väga jõukas talu, väga rikkad inimesed olnud seal. Aga need surid ära ja muist aeti laiali.

[T. J.: Jutustaja joonistab jutustamise ajal paberile tegevuspaiga: kus on Lubjaahju talu, kus kääpaaugud, kus need suured puud, Sillaotsa talu ja Liisu enda kodu, vt skeemi.]

Lubja[ahju] talus olin ma tööl novembri õhtal linu puhastamas. Mul oli töötasuks saada üks puud rukkijahu. Vanaema andis mulle koti ja ütles, et mine too ainult 20 naela, mis sa tervet puuda tood. Aga peremees ütles, et sa oled tugev tragi tüdruk, paneme puuda sulle kotti. Oleks ma nüüd 20 naela võtnud, siis oleks kotisuu olnud nii [näitab käega, et kotisuu oleks olnud kokku seotud piisavalt pikalt ja ta oleks saanud kotti üle õla kanda nii, et ta ei oleks pidanud olema kummargil]. Aga 


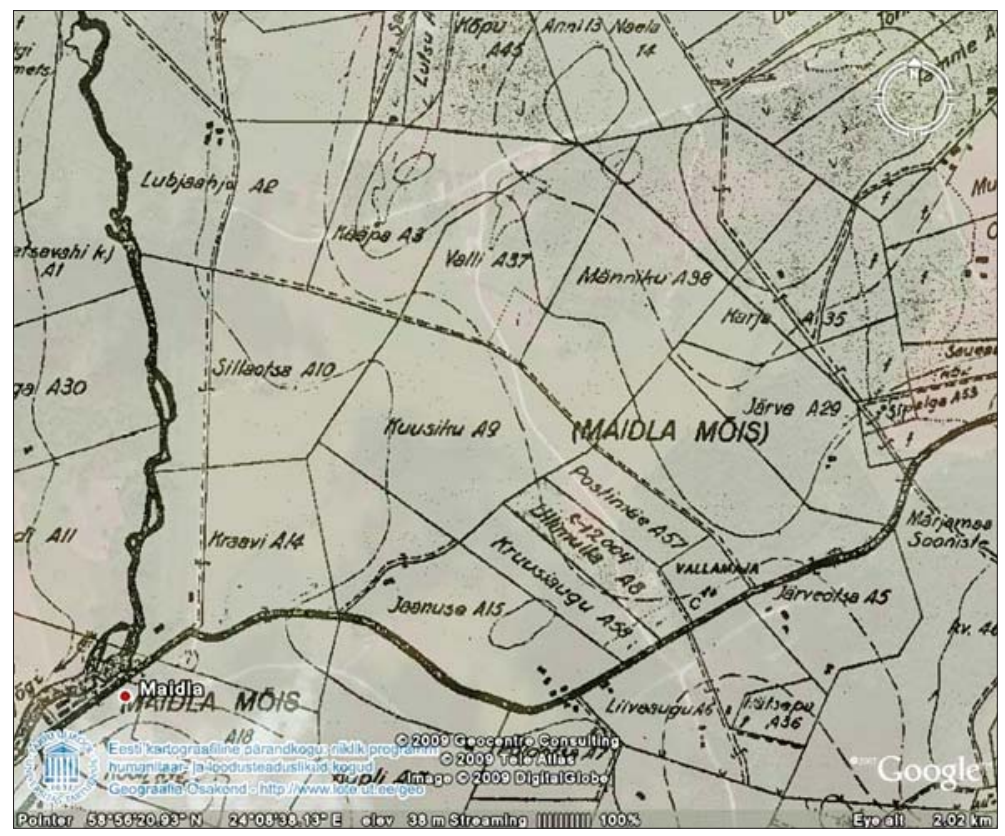

Eliise Tamme kääpaloo tegevuspaik: Lubjaahju = Lubjaahju A2; Sillaotsa talu = Sillaotsa A10; kä̈̈paaugud = Kä̈̈pa A3 ja Valli A37; suured puud = Maidla mõisa park ?; Liisu enda kodu $=$ Ullimulla.

tema pani selle mulle niiviisi õlale, ja mu käsi oli sedamoodi ja läksin otse edasi otseti. Kuuvalge oli ka ja mina hakkasin üle põldude tulema. Tea kas oli kilomeeter maad niimoodi otse. Nägin, need suured puud veel paistsid. Tulin ja lasin koguaeg laulujoru sedamoodi...

Järsku vaatan, mina olen kusagil õues, aknad on valged, kuskohas ma olen. Võtan siis õla pealt ära, võtan seasi kaenlasse - no kuskohal ma olen? Aga siis selle talu koerad hakkasid haukuma ja siis ma sain aru, et ma olin siia kohta tulnud [näitab oma joonisel Sillaotsa talu]. No mismoodi ma ikka läksin?

Ja siis ma tulin koju ja räägin vanaemale, et näe, misuke asi mul oli. Vanaema ütleb: Sa astusid kä̈̈pa teeraja peale. Siis vanaema ütles veel, et kui sa oleksid üle teeraja astunu, siis ei oleks olnud. Aga et sa just teeraja peale astusid, sellepärast eksitas.

Vaata, vanad inimesed uskusid niisuguseid asju. Mina ei uskunud.

EKRK I 90, lk 113-128. Jutustanud Eliise Tamm (1904-2002) 1990. aastal Ristil. Jutusündmus leidis aset Kullamaa kihelkonnas Maidlas vahetult pärast Esimest maailmasõda. Tekst on helisalvestuse ümberkirjutus. Kogujad, eesti filoloogia I kursuse üliõpilased Mari Koik, Jakko Väli, Terje Kruusimaa. 
Aino Laagus toob välja järgmised tekstitunnused (Laagus 1973: 405): metshaldja muistendid kui uskumuslikud jutustused [on] üles ehitatud argisündmustele, mis toimuvad reaalses geograafilises ruumis, nii nagu ka eeltoodud näitetekstis: jutustaja tuli novembri õhtul Lubjaahju talust linu puhastamast koju. Nende juttude aluseks on otseses või kaudses tähenduses reaalne käitumine ja kogemus, mis samuti on eeltoodud loos nähtav. Tõsielusündmus neis lugudes esitatakse väljaspool kahtlust olevana. Selleski veenab meid jutustaja jätkuvalt: kas te usute mu juttu või ei, aga ma räägin tõsiselt; palju-palju aastaid tagasi olnud seal jõukas talu...;ja siis ma tulin koju ja rääkisin vanaemale; vanad inimesed uskusid niisuguseid asju. Jutustamise eesmärgina toob Aino Laagus esile vajaduse informeerida teisi kollektiivi liikmeid oma kogemustest, võrrelda oma kogemust teiste kogemustega. Eeltoodud jutustuses esitatakse see nii: minategelane kõneleb temaga juhtunust vanaemale, kelle sõnade kaudu viiakse jutustatud üksikjuhtum suhtesse pärimusrühma teadmiste ja kogemusega. Tõenäoliselt ei ole siin rääkimise ajendiks mitte niivõrd uskumuslik kogemus kuivõrd üllatus eksimisest, sest jutustaja rõhutab loo lõpus, et ta ei uskunud niisuguseid selgitusi. See omakorda osutab asjaolule, et sama pärimusrühma raames (teatakse kääpalugusid) on esindatud erinevad suhtumised pärimusse (kas uskuda kääpa teerajale astumisest tingitud eksitamist või mitte).

Eeltoodud ekskursist nähtub, et situatsioonianalüüsi saab rakendada tekstidele, mida iseloomustab esmalt see, et need seostuvad tõsielukogemusega; teiseks see, et nende eesmärk on jagada oma elamusi ja kogemusi ning võrrelda neid pärimusrühma liikmete omadega (mis tähendab ühise teadmuse loomist, oma kogemuste suhestamist üldiste teadmistega); kolmandaks see, et nende jutustamine kinnistab (või vaidlustab) teatud arusaamasid, kujundades kohalikku pärimustraditsiooni. Kuid kuhu selles analüüsis asetub rahvaluulekogujale rääkimise situatsioon ja kuidas mõjutab loo teaduslikku tõlgendust fakt, et analüüsitakse kirja pandud suulist esitust? Need küsimused ei ole situatsioonianalüüsile omased, sest rõhud asetuvad mujale: situatsioonianalüüs kohandub kirja pandud (või ka kirjutatud) tekstidele, kus sõna- ja fraasitasandite võrdlemise kaudu uuritakse teksti tunnuseid. Aino Laaguse eesmärk on kirjeldada erinevaid tõsielukogemusi sisaldavaid usundilisi tekste ühtsetelt alustelt: kuidas leida ühine nimetaja tegevustele, tegevuskohtadele, tegevusajale - igas jutustatud tekstis on need tõsielusündmuse kordumatusest tulenevalt erinevad. Metshaldjatekstide ühtseks tunnuseks (teate sisuks) on Aino Laaguse järgi situatsioon: Muutuvad küll elemendid, mis kuuluvad situatsiooni, kuid situatsioon ise jääb enamvähem muutumatuks: inimene astub kontakti üleloomuliku olevusega, haldjaga. Teated metshaldjate kohta kujutavad endast märke, mis modelleerivad tegelikke või mõeldavaid situatsioone, 
kus inimene näeb, kuuleb, kogeb haldjat, tunnetab tema olemasolu (Laagus 1973: 406). Kuigi situatsioonianalüüsi raamid pakkusid midagi olulist ka üheainsa teksti lähivaatluseks, on situatsioonianalüüsiks vaja juurde otsida teisi kääpatekste, sest meetodi tuum peitub samasisuliste tekstide omavahelises võrdlemises.

\section{Situatsioonianalüüsi teaduslikud paralleelid}

Situatsioonianalüüsi aluseks on arusaam, et tõsielust jutustamisel ei toimi ainult peegeldussuhe, vaid jutustuste abil ka luuakse tõsielusündmusi (teisisõnu, tekstid modelleerivad tõsielu-situatsioone). See haakub strukturalismiväliste uurimustega, milles rõhutatakse, et tõsielust jutustamisel ei toimi mitte ainult teadmine tõsielus toimunust, vaid ka jutustamisvõtete ja -traditsiooni mõju sellele, mida ja kuidas jutustatakse (vt nt Hiiemäe 1978: 38-47). Strukturalistlike meetodite erijoon seisneb aga nimelt keskendumises teksti ehituslikele tunnustele, millest johtuvalt ei kõnelda (erinevalt soome meetodist lähtuvatest võrdlev-ajaloolistest uurimustest) peamiselt teemadest ja motiividest, vaid analüüsi keel väljendab teksti raamistikule omaseid tunnuseid. Aino Laaguse silmis on sellised analüüsispetsiifilised mõisted 'situatsioon' ja 'komponent'. Nagu eelpool mainitud, eristab Aino Laagus metshaldjatekstides kahte situatsiooni, kasutades mõisteid 'tegevussituatsioon' (tekstis jutustatav tegevus, kujutelmad, mida jutus edastatakse) ja 'teatamissituatsioon' (tegevussituatsiooni edasiandmine). Mõlemad situatsioonid jaotuvad omakorda 'komponentideks': tegevussituatsiooni komponendid on tegevus, aeg, koht (ruum), atribuudid, haldjas ja nn tekstiväline komponent (üldised asjakohased kujutelmad, arusaamad ja uskumused, mis otsesõnu tekstis ei kajastu); teatamissituatsiooni komponendid on teataja, tegevussituatsioon, kuulaja, kõnelemise eesmärk, teataja suhtumine kõneldavasse, teatamisaeg ja -koht. Komponentide fikseerimise abil luuaksegi uurimuseks vajalik tekstide võrreldavus.

Miks on 'situatsioon' tekstianalüüsi seisukohalt keskne? Teatamissituatsiooni kaudu kujundatakse individuaalse elu fakt sotsiaalseks kogemuseks, kirjutab Aino Laagus. Kuid miks mitte 'jutustamine' kui fakt, miks just 'situatsioon'? Aino Laagus rõhutab, et situatsioonianalüüs on rangelt tekstianalüüsi meetod: Ainult see, mis tekstis avaldamist on leidnud, võib olla uurimisobjektiks. Seega uurida saab ainult seda, mis on sõnastatud (kirja pandud). Tänapäeva uurija ette kerkib aga küsimus kontekstist: mil määral mõjutab teksti tunnuseid (konkreetset suulist esitust, selle salvestust) selle teksti loomis(jutustamis)olukord?'15 Tulen selle küsimuse juurde hiljem tagasi. Hetkel aga küsin, miks situatsioonianalüüs võiks olla tähelepanuväärne tänapäevases konteks- 
tikeskses (tõlgenduslikus) uurimises, peatudes kolmel märksõnal: teksti täppisanalüüs; jutustamisolukorra roll tekstisaamisloos; tõsielu ja jututõe omavahelised seosed.

Esiteks pakub situatsioonianalüüs eeskuju tekstide täppisanalüüsiks. Situatsioonianalüüs toimub nii, et kogu analüüsitav tekst jaotatakse selles tekstis kasutatud sõnastust järgides verbaalselt eelnimetatud komponentideks. See muudab analüüsitavad tekstid omavahel võrreldavaks, sest komponent kui üldkategooria ühendab tekstides esinevad sama kategooria variandid. Näiteks metshaldjatekstide tegevuskohaks kui komponendiks on tavaliselt küll mets, ent see võib avalduda erinevate metsaliikidena (kuusik, kadastik), osana metsast (tihnik, lagendik), üksikobjektina (puu, põõsas, känd). Tähtis on, et tekst jaotatakse kategooriate vahel täielikult (mitte valikuliselt) ja jaotustes kui kirjeldusüksustes säilib teate terviklikkus (seotus teksti kui tervikuga). Nii pakub situatsioonianalüüs kvantitatiivseid uurimisvõimalusi, vastates näiteks küsimustele, millised on sageliesinevamad haldjaga kohtumiskohad, millise haldjaga kohtutakse ja mil viisil. Kuigi analoogiliste tekstide puhul (nt küsimustike või kogumisvõistluste abil kogutud teemavastused ja -jutustused, eriti aga pikad tekstid nagu elulood) selline täppisanalüüs ei tööta, saab (ja ilmselt on aeg rõhutada, et tuleb) arvestada situatsioonianalüüsi täpsust, et mitte sattuda jutuanalüüsis muljete valda. ${ }^{16}$

Tõsielust jutustamise kui jutu ühe sündmustasandi kõrval eristab Aino Laagus teisegi teksti kujundava sündmuse tasandi, mille ta nimetab teatamissituatsiooniks. Selle sündmustasandi eristamine lähendab Aino Laaguse väljatöötatud uurimisviisi pärimuse kommunikatiivsete aspektide uurimisega: teksti sellel tasandil ilmnevad uskumuste sotsiaalsed tahud ja nende tähendusmuutused. Situatsioonianalüüs, seostudes jutustamisega (ja mitte ainult jutustatava sündmusega), annab viiteid jutustamisolukorra osale valida just need seigad tekstivälisest tegelikkusest, mis on leitavad tekstist. Situatsioonianalüüsi sellele tahule pakuvad paralleele näiteks Skandinaavia biograafilisi jutustusi käsitlevad uurimused, milles rõhutatakse, et sündmused narratiivis ja jutustamine [ise] kui sündmus, ei ole üks ja seesama (Marander-Eklund 2006: 142; vrd Palmenfelt 2006). Neis töödes lähtutakse Katharine Galloway Youngi uurimusest Taleworlds and Storyrealms. The phenomenology of narrative (Jutumaailmad ja loosfäärid: narratiivi fenomenoloogia, ilm 1987), kus autor pakub analüütilise mudeli jutu (konkreetses tekstis sõnastatu), loo (jutu aluseks olevad sündmused, jututraditsioon, teadmised juhtunust ja esitusviisidest) ja vestluse (loo jutustamisolukord) omavaheliste seoste kirjeldamiseks. Kirjeldatud lähenemisviisid võimaldavad pöörata elukogemusele tuginevate lugude analüüsis enam tähelepanu kas ühele või teisele eeltoodud tasandile tekstis, pidades samal ajal silmas nende tasandite omavahelist seotust. Nii võib uurija 
keskenduda jutustatavate sündmuste valikule (millest räägitakse, millest vaikitakse konkreetses situatsioonis nagu näiteks intervjueerimine uurimuse tarbeks) ja nende valikute põhjendusele (nt Palmenfelt 2006) või jutu tegelasrollidele, mida jutustaja kontrollib ja kujundab (Marander-Eklund 2006) ${ }^{17}$. Tegelasrollide analüüsile keskenduv lähenemisviis assotsieerub omakorda vene strukturaal-semiootiliste tõsielu-jutustuste uuringutega, kus kasutatakse mõistet 'eludramaturgia': tõsielujutu tegelased ja sündmused on omavahel seotud, sest tegelased peavad saama täita jutustuses teatud rolle (Nekljudov 1998, vrd Lotman 1991: 366-385).

Kolmandaks. Tekstide analüüs viis Aino Laaguse järelduseni, et haldjas seostub situatsiooniga tervikuna ega piirdu pelgalt teatud olendi kirjeldamisega. Haldjas on terviklik situatsioon, mida inimene üle elab, kõik selle situatsiooni komponendid [---] ja nende omavahelised suhted (Laagus 1973: 412). Analoogiliselt võib mõista ka pärimusajaloolisi tekste: ${ }^{18}$ küsimus ei seisne mitte üksnes üksikute olukordade (sündmuste, perioodide) läbielamiste vahendamises, vaid nendest kujunenud kogemuste seostamises minevikutõlgendusega üldiselt. ${ }^{19}$ Situatsioonianalüüs ja selle edasiarendused (nagu ka paralleelid tõsielukogemusi vahendavate juttude analüüsis) on olulised jututõe mõistmise seisukohalt. Elukogemustele rajanevate juttude allikaloolistes aruteludes, eriti elulugude uurimises, on esil küsimus sellest, mil määral saab jutustusi kasutada ajaloolise tõe väljaselgitamiseks (vt ülevaadet aruteludest nt Jaago 2007 [2001]). Et mõista kogemusjuttude tõde, tuleb analüüsida tekstis sünkroonselt nii jutu-, loo- kui ka vestlusvälja (kui kasutada Katharine Galloway Youngi mõisteid), arvestades seejuures nende tasandite omavahelist seotust. Kogemusjuttude tõde ei seisne tegelikkuse faktide objektiivses peegeldamises, vaid läbielatu mõtestamises. Tõsielu tõlgenduslikkust rõhutavad nii suulise ajaloo (vt nt Portelli 1997: x, 4; 2000 [1991]: 67), Tonkin 1999 [1992]: 93-94) kui ka elulugude uurijad (vt nt Andrews 2008: 86). Kui tõsielujutustusi analüüsides ei arvestata erinevaid tasandeid (lugu, tekst, vestlus) ja nendevahelisi seoseid, ei olegi võimalik mõista tõsielujutus peituvat tõde (fakte nende tõlgenduses). Teksti kui tegelikkuse fakti omakorda saab mõista traditsiooni (kultuuri) kaudu: lugu ei sünni üksnes tõsielusündmuse läbielamisest tõukudes, vaid tõsielusündmuse kogemist mõjutavad sündmuseelsed kogemused (sh ka selle sõnastused). Sellest tulenevalt ei kirjeldata tõsielufakte ühel ja samal viisil, sest neid ei tajutudki samasugusena. Teisalt vajab jutustamine tõsielu jutuks ülekandvaid tehnikaid (vrd Hiiemäe 1978, Jaago 1995, Voolaid 2001). Kuigi situatsioonianalüüs ei võimalda leida otseselt tõsielu ja sellest jutustamise omavahelisi seoseid (erinevalt ajaloosündmustest kõnelevatest juttudest puuduvad kõrvutamiseks ju vajalikud andmed tõsielufaktide kohta), võimaldab see siiski tekstide omavahelise võrdlemise abil avastada traditsiooniomaseid jutustamisviise. 
Tõsielu ja jutusündmuste omavaheliste seoste uurimise seisukohalt osutuvad eriti olulisteks viiteid jutustamisolukorrale: kuidas sõnastatakse oma suhe jutustatavasse sündmusesse, levinud arvamustesse selliste asjade kohta, vestluspartneri veenmine jms, mis esmapilgul jäävad jutustava sündmuse varju.

\section{Kontekstianalüüsi näide}

Tulles tagasi situatsioonianalüüsi ja kontekstianalüüsi võrreldavuse juurde, kasutan näitena taas Eliise Tamme jutustatud kääpalugu. Situatsioonianalüüs nõuaks samalaadseid tekste, kontekstianalüüs aga enam andmeid jutustaja, jutustamisaja ja -koha, nagu ka jutustatava sündmuse aja ja koha kohta. Kontekstianalüüsi seisukohalt osutuvad oluliseks esmalt jutustava sündmusega seotud asjaolud: toimumiskoha täpsem geograafia, täpsem toimumisaeg jms. Et seda täpsemalt mõista, on vaja lisateavet Maidlast, kus jutusündmus aset leidis: vaadata fotosid, jälgida täpsemalt jutustaja(te) ja kohalikku maastikku ning ajalugu teadvate inimeste selgitusi. Teiseks pakub huvi toimunu üle peetud aruteluosa jutustuses. Eliise Tamme loos on esil jutustaja suhe vanaemaga, kuid külakogukond jääb tagaplaanile (vanad inimesed uskusid niisuguseid asju). Hoopis erinevalt avaneb kogukondlik maailmapilt aga näiteks 1890. aastal samas külas sündinud mehe mälestustes. Kirjeldatakse seda, kuidas välk lõi suure kivi sisse:

Sel õhtul, kui karja koju ajasime, tuli vanaperenaine põlluväravas meile vastu ja küsis, kas meil hirmu ka oli ja kas me seda suurt mürtsu ka olime kuulnud. "Kuulsime küll, aga midagi ei näinud. Vihma sadas!" Vanaperenaine ütles, et me ei võinudki näha, sest välk oli löönud heinamaa äärest natuke maad eemal lagedal põllul asuvasse määratu suurde raudkivisse, mille küljest oligi suur tükk eemale karanud. Läksime selle suure kivi juurde ja katsusime käega. Kivi tundus olevat veelgi soe. Teised inimesed käisid seda kivi vaatamas ja arvasid, et küll selle kivi all ikka vist mõni muistne rahalaegas peidus on, kuidas muidu välk just selle kivi sisse lõi, kuna ümberringi teisi kive ka oli. Koolmeister arvas, et see kivi pidi rohkem rauda sisaldama, siis sellepärast see kõmakas käiski. Kaarel arvas sedasama, aga siis arvasid, et kuluks õige järele uurida, vast ehk ikka ongi selle kivi all midagi peidus. Lubasid koolmeistriga selle asja edaspidi käsile võtta.

August Tarendi (1890-1971). Memuaarid I. Lapsepõlv, lk 336. Mälestused on kirjutatud 1960. aastatel peamiselt varasematele märkmetele ja päevikutele tuginedes. Käsikiri Kalev Jaago valduses. 
Sündmusse on haaratud nii jutustaja ise kui ka teised külainimesed. Kirjeldatakse nii seda, kuidas ise seda sündmust karjas olles kogeti (äikeselööki kuuldi; kivi oli katsudes soe), kui ka seda, kuidas teised olid seda kuulnud ja näinud ja sellest nüüd omavahel rääkisid. Lõpuks kirjeldatakse arutelusid, miks välk just selle kivi sisse lõi: rahvapärimuse järgi pidanuks selle kivi all, mida välk kätte näitab, rahalaegas maetud olema. Kooliõpetaja seletust mööda olevat aga sellise kivi rauasisaldus lihtsalt väga suur.

Miks teised kogukonnaliikmed Eliise Tamme loos nii määratlematuks jäävad? Et selle vastust leida, on taas vaja lisaandmeid. Esmalt olid kasutada 1990. aastal teised Eliise Tamme esitatud lood ja teda külastanud rahvaluuleõliõpilaste kogujapäevikud. ${ }^{20}$ Artikli kirjutamise ajal oli võimalus lisateavet hankida Eliise Tamme tütrelt. ${ }^{21}$ Asjakohaseks osutusid nii Eliise Tamme eluloosse puutuvad andmed kui ka tema tütre suhtumine eeltoodud eksitamisloosse. Ilmneb, et Eliise Tamm on pärit Tallinnast, kuhu tema vanavanemad olid Maidlast lähtunud tööotsingutes elama asunud. Esimese maailmasõja ja revolutsioonisündmuste eest tuli Eliise vanaemaga Maidlasse, kuhu ta jäigi 1939. aastani (siirdudes siis Kullamaale ja 1941. aastal Ristile).

Eliise Tamme eluloost tulenevalt on ootuspärane, et tema lapsepõlveaegne maailmapilt ning kohaloo tundmine on regionaalselt mitmeplaaniline (Tallinn, Maidla), ning teisalt piiratud perepärimusega (19. sajandi lõpu ehk mõisaaegset Maidla külakogukonda tunneb ta oma vanaema ja vanaisa jutustatud lugudest, milles nemad on omakorda kõnelenud oma vanemate elulugudest ja argielust).

Üks kontekstiuurimise küsimusi võiks olla, mil määral kuulus see lugu Eliise Tamme juturepertuaari üldiselt ja mil määral oli see räägitud rahvaluuleüliõpilaste huvist just niisuguseid lugusid kuulda? Viimasele küsimusele ei saa muidugi ühest vastust anda, ent sellise küsimuse püstitamine lähtub oma loomult konstruktivistlikest arusaamadest. Eeldatakse, et lugu sünnib sellisena just jutustamisolukorra toimel, mitte pelgalt valmis jutu taasesitamisel. Mõneti see olemasolevatest andmetest siiski ka ilmneb. Nimelt kurdavad esimeses kursuse lõpetanud rahvaluuleüliõpilased Mari Koik, Jakko Väli ja Terje Kruusimaa oma kogujapäevikus, et inimesed teavad küll jutustada lähemast ajaloost, aga rahvajutte ei ole ja laule enam sealkandis rahvas eriti ei mäleta. See sõnastus viitab üliõpilaste rahvaluule välitöö ootustele - rahvaluuleõpikust omandatud klassikaliste rahvaluule liikide tundmisele ehk eeldusele, et kogutakse nn vanu laule, klassikalisi rahvajutte ning usundi- ja kombeloolist materjali, mille tekstilised eeskujud pärinevad 19. sajandil kogutust. Selline eeldus 20. sajandi lõpu välitöödel loomulikult tuge ei leidnud.

Üliõpilaste kogujapäevikust ilmneb tõesti, et kääpaloo rääkis Eliise Tamm rahvaluuleüliõpilaste küsimise peale. Teised tema lood liigitaksin perepäri- 
muse (suguvõsaajaloo, argiajaloo) valda. Lisaks esitas ta kaheksa noorte suhete teemalist lõppriimilist laulu ja teadis Koluvere krahvi lugusid, mida selle välitöö raames teisteltki kuuldi ja mida selle tõttu rahvaluuleüliõpilased samuti küsida oskasid. Eliise Tamme tütart külastades tahtsin teada, kas tema ema on rääkinud kääpast ja sellest, et kääpa teerajale astumine (olgugi, et vanaema selgituste kohaselt) teda niimoodi eksitas. Tütar seda lugu kääpa ja eksitamise märksõnade kaudu ei teadnud (kääpaid teadis ta väljakaevamiste järgi: sellest kalmest on ju nii palju räägitud nü̈̈d ja uuritud), ja palus mul seda lugu täpsemalt jutustada. Kui olin seda teinud, väitis ta: See kõik on õige, sellepärast et ta ise rääkis niimoodi, et kui tema ôhtul kuskilt töölt tuli, pimedas juba, siis tema kogu aeg laulis. Ja siis vanaema oli kuulnud juba, et kui Liisi laulu on kuulda, siis Liisi juba tuleb. Seejärel pidas ta tõenõoliseks, et ema võis õigelt teelt kõrvalrajale astuda: Kõik on väga tõenäoline ju... mis need põlluvaheteed siis olid, kõik on ühesugused seal, ja ta läks siis kuskil teise teeraja peale ja laulujoru ajas [---]. Lõpuks kinnitab ta sedagi, et töötasuks oli toona kindlasti midagi toiduainetest, aga mitte raha. On omapärane, et esmalt tundis jutustaja selles loos ära ema laulmise (ta väidab ju, et ema ise rääkis niimoodi), mis folkloristile on selle loo põhjal heal juhul taustateave: kui see oligi märgatav, siis ei tundu see kuidagi jutusündmustikus määrav olevat. Kuid kuna tütar tundis selles, 1990. aastal rahvaluuleõliõpilastele esitatud loos ära oma emalt kuuldu (see kõik on õige, sellepärast et ta rääkis niimoodi...), siis võib ka järeldada, et Eliise Tamme räägitud (samad) lood tõid esile üldise teadmise erinevad aspektid, sõltuvalt jutustamissituatsioonist, sh jutustamis-eesmärkidest. Võib järeldada, et temale oli ema rääkinud selle loo argielulisest poolest, rahvaluulekogujatele aga usundilist maailmapilti esitledes.

"Sama lugu" on tõik, mis seob situatsioonianalüüsi kontekstianalüüsiga: teadmine kui võimalus jutustada millestki realiseerub teatud jutustamisolukorras. Jutus ei peegeldu kogu teadmine asjast, vaid olukorrast tulenevalt antud hetkel oluline osa tervikteadmisest. Erinevus situatsiooni- ja kontekstianalüüsi vahel seisneb aga selles, et esimesel juhul keskendutakse teadmise sõnastuslikule tasandile, teisel juhul aga tõlgendusele (või õigemini: tõlgenduse teatud tasandile, mille loobki kontekst, sest kontekste võib olla ju palju jutustava sündmuse ajalooline kontekst, pärimuskontekst, jutustamiskontekst, arhiivikontekst, teiste dokumentide kui tekstitüüpide kontekst jne). 


\section{Kokkuvõte}

Situatsioonianalüüs toimis teabekesksete lugude analüüsil. Neis lugudes on jutustamisolukorra mõju teksti ülesehitusele (sh motiivide valikule) tunduvalt enam esil kui fiktsionaalsete lugude (muinasjutt, anekdoot, teatud laadi linnalood ${ }^{22}$ ) puhul. Kontekstianalüüsis tuuakse uurimisväljale teist tüüpi tekste või teist laadi andmeid, mis võimaldavad tegelda enam teksti "ümbrusega". Näiteks suulistele mälestustele ja ajalooarhiivi kirjalikele dokumentidele tuginev suguvõsaajaloo võrdlev uurimine joonistas välja teatud jutustamis- ja mäletamisskeemid, millest märkimisväärseim on nn aegade kokkujooks (Jaago 1995). ${ }^{23}$ Ajaloolise jutu-uurimise ${ }^{24}$ võimalusi kasutades võib fikseeritud tekstide kaudu näha loo arengut - sündmusajast jutustamisteni toimuvaid muutusi. Ilmneb näiteks, kuidas loost kaovad isiku kogemusega seotud aspektid (Kalda 2006: 101-103) või kuidas ajastu muutudes saavad senised jutumotiivid hoopis uue tõlgendusraami (Beyer 2000). Jutustaja vaatepunktide võrdlemine dokumendi vaatepunktidega pakub võimalusi näha ajaloosündmuste tõlgendamise dünaamikat, mida kujundavad nii ajadistantsi suurenemine kui poliitiliste taustade vahetumine (nt Jaago 2009). Kontekstianalüüs annab võimalusi uurijale oma tõlgenduse tõenäosuslikkuse kontrolliks (vt nt Apo 2003).

Kontekstianalüüsi uurimisfookusse asetatakse nt jutustaja identiteediloomega seotud küsimused, jutustaja sotsiaalne ja kultuuriline kontekst, lokaalse ja üldise seotuse teemad jms (vt nt Phoenix 2008). Kontekstianalüüsi ohud peituvad aga just tekstist eemaldumises. See võib toimuda teksti pealispindse kasutamise, aga ka uurija keelekasutuse tõttu, eriti teadusliku mõisteaparatuuri ületarbimisel, kus viimane hakkab domineerima materjali üle (näide, millele viitas ka Mare Kalda eeltsiteeritud lõik, Kalda 2006: 105).

Situatsioonianalüüs pakuks inspiratsiooni tõsielujutustuste täpsemaks vaatluseks. Situatsioonianalüüsi ja kontekstianalüüsi võimalusi kombineerides saab enam jälgida uuritava allikmaterjali detaile ja nende omavahelisi seoseid üldisemate taustadega. See võimaldab vältida uurija retseptsioonide meelevalda sattumist (äärmuslikuna esitatuna - praktikas see ühtegi uurimust tervikuna ei iseloomusta - , on see nt olukord, kus uurija ei erista oma vaadet jutustaja omast, ${ }^{25}$ või kus uuritav materjal on uurija jaoks vajalik pelgalt uurija enda tekitatud probleemidele vastamiseks ${ }^{26}$ ). Ühtlasi võiks selline teksti täppisanalüüsi kui lähenemisviisi areng sobida Eesti folkloristikale loomuomaselt: on ju Eesti folkloristikat jätkuvalt iseloomustanud tekstist lähtuv vaade, s.o usaldus teksti kui allikmaterjali vastu. 


\section{Kommentaarid}

${ }^{1}$ Artikli valmimist on toetanud sihtfinantseeritav teadusteema SF0180139s08 ja Euroopa Liit Euroopa Regionaalarengu Fondi kaudu (Kultuuriteooria Tippkeskus).

2 Strukturalistlikud lähenemisviisid Eestis on toetunud suuresti Juri Lotmani ja nn Tartu-Moskva koolkonna töödele (vt koolkonna kujunemisest nt Nekljudov 2003: 29-31). Juri Lotman vastandab teksti strukturaalanalüüsi positivismitraditsioonile, viidates teksti osa ja terviku omavaheliste seoste mõtestamise erinevustele: Niisugusel analüüsil [T. J. strukturaalanalüüs] ei tajuta teksti teda moodustavate osade mehhaanilise summana ja nende elementide "eraldiolek" kaotab absoluutse iseloomu - iga element realiseerub vaid suhtes teisega ja kogu teksti struktuuritervikuga. Selles mõttes on strukturaalanalü̈̈s vastunäidustatud positivismi atomaarsele-metafü̈silisele traditsioonile XIX sajandil ning on kooskõlas meie aastasaja teadusotsingute põhivaimuga (Lotman 1991 [1972]: 32).

${ }^{3}$ Eesti folkloristikas annavad pärimustekstide täppisanalüüsi otsinguist märku (programmilised) artiklid, milles keskendutakse põhiliselt tüpoloogiale ja tekstikriitikale (need meetodid rakendavad vähem või rohkem ka teksti struktuuri analüüsi): vt laulude alalt nt Laugaste 1962; Tedre 1964; lühivormide uurimisest vt ülevaadet Krikmann 2001. Ka Aino Laaguse kõnesoleva töö üks (kaugem) eesmärk on rakendada situatsioonianalüüsi tulemusi tekstide tüpologiseerimisel, sest ta küsib: Kui aga kõik [haldja-] teksti moodustavad komponendid võivad muutuda, mis on siis uskumuslike jutustuste invariantne osa? Milliste tunnuste alusel on võimalik eri elementidest koosnevaid tekste ühistesse tü̈̈pidesse koondada? (Laagus 1973: 405-406). Oma töö erinevust varasematest uurimustest näeb ta faktis, et seni koondati tähelepanu teatud tahkudele (nt usundiliste tekstide tegelastele nagu näkk, kratt jne ning nendega seotud kujutelmadele) ja muu andmestik jäi tagaplaanile. Kui aga tahame neist tekstidest saada autentseid teadmisi, tuleb arvesse võtta kogu tekstis sisalduv andmestik (Laagus 1973: 404). Strukturaalfolkloristika kujunemist Nõukogude Liidus seostab vene folklorist Sergei Nekljudov radikaalsete muutustega humanitaarteadustes 1950. aastate teisel poolel ja 1960. aastate alguses. Just siis andis energiliselt endast märku uus uurimissuund, mis seadis eesmärgiks täpsete meetodite kasutamise ühiskonnateadustes [---] mis pidi viima [---] tekstide rangema analüüsini (Nekljudov 2003: 29). Isikulooliste narratiivide struktuuri tänapäevasel uurimisel rõhutatakse sotsiolingvist William Labowi 1972. aastal ilmunud teose Language in the Inner City tähendust (vt Patterson 2008: 22).

${ }^{4}$ Rahvausundi kujunemist individuaalsete elamuste ja pärimusrühmateadmiste omavahelistes seostes (ühtlasi traditsiooni ja variatsiooni seoseid) on käsitlenud Lauri Honko haldjaterminoloogia-teemalises artiklis, mis ilmus 1980. aastal Outi Lehtipuro koostatud rahvaluuleuurimismeetodite kujunemisele ja eriti nende viimastele arengutele pühendatud artiklite kogumikus Perinteentutkimuksen perusteita.

5 Usutavus ei ole praegu päevakorral. Tõsielulisus viitab sellele, et tegemist ei ole teadlike fiktsioonidega.

${ }^{6}$ Mõiste 'modelleerimine' on otseselt seotud Juri Lotmani tolleaegsete töödega. Vt nt artiklit "Kunst modelleerivate süsteemide reas" Lotman 1991 [1967]: 8-31. Kunsti kui modelleeriva süsteemi sisuks on tegelikkuse maailm, mis on tõlgitud meie teadvuse keelde, mis omakorda on tõlgitud antud kunstiliigi keelde (Lotman 1991 [1967]: 9).

7 Eelteadmise või etteantuse ja ainulaadse või individuaalse elamuse omavaheliste seoste kohta vt võrdlevalt nt Honko 1980; Arukask 2000. 
8 Vt konstruktivismist teaduses (täpsemalt, teadmisest kui sotsiaalsest konstruktsioonist) nt Kallas 2007.

9 Mõned erandid on esile kutsutud traditsiooniliste lähenemisviide kombineerimisest interdistsiplinaarsete uurimisviisidega, nt feministlik uurimine (Ehin 2004), autobiograafiline ja soouurimuslik ekskurss lauliku-uurimustes (Kalkun 2004: 3238), biograafiline meetod (Oras 2008: 32-35). Sellegipoolest arutletakse teooriate üle vaid selles mahus, mis pakub tuge näiteanalüüsile. Vrd nt konstruktivismikäsitlusi pärimusliku ajaloo uurimises Soome uurijate töödes, kus sedalaadi teoreetilised raamid tõstetakse käsitluses esiplaanile: Knuuttila 1994: 23 (kus ta võrdleb fenomenoloogilisi, hermeneutilisi ja hermeneutilis-fenomenoloogilisi ehk etnometodoloogilisi erinevusi traditsioonilises ja konstruktivistlikus uurimises, kus esimesel juhul on esil nähtuste fikseerimine, teisel juhul nähtuste jälgimine protsessis ja kolmandal juhul jutustamisprotsessi aktiivsus minevikupildi loomisel); Fingerroos \& Haanpää 2006: 32-36 (kus nad esitavad Jürgen Habermasi teadmistealastele töödele toetudes skeeme sellest, kuidas pärimuslikus ajaloos on uuritud meenutamise subjektiivsust ja 'tõde').

${ }^{10}$ 1687. aastal koges Torsten Grön nägemusi ja kannatas fü̈siliselt (tugevad valud, halvatus). Tõenäoliselt suri ta samal (või järgmisel) aastal. Surma eel määras ta testamendiga 400 tukatit kirikukella hankimiseks ja 100 taalrit vaestemajale. Ta maeti Rõngu kirikusse kantsli alla. Tema pärandit ei leita (Kalda 2006: 102).

${ }^{11}$ Vrd nt Arvo Krikmanni esitatuna lühivormide uurimise kontekstis: [---] on pidev oht, et uurija mõistab ajaliselt ja / või kultuuriliselt kauget ainet vastavalt omaenda maailmapildile (kategooriale, väärtustele), mis on ebaadekvaatne [---] (Krikmann 2001: 15).

${ }^{12}$ Kääbas on surnu vaimu lokaalne - Läänemaal tuntud - nimetus, nt: kääpad on meesterahva moodi olevused, valgeis riideis; surnute hinged, kes tagasi tulevad, nim kä̈̈pad (Loorits 1998 [1927]: 97; 130-131).

${ }^{13}$ Sandra K. D. Stahli mõiste personal experience stories on eesti keelde tõlgitud "isikliku kogemuse jutud“" (Stahl [a-ta]). Stahl esitab selle mõiste rahvajutu liigi- ehk žanrimõistena. Kontekstikeskses uurimuses, kus ei keskenduta rahvajutu liigitussüsteemile, kasutatakse seda mõistet vabamalt, rõhutades tekstiomaduste asemel tõsielu ja jutusündmuste vahelist seost. Nt Mare Kalda (2006) kasutab terminit "elamust / kogemust kajastav isikulugu". Analoogilisse kasutusseosesse kuuluvad üksteisega ühisosa omavad, aga siiski erinevad mõisted nagu "elamuslugu", "kogemuslugu", "teemajutustus", "elukogemuslugu", "elulugu”. Ingliskeelse termini experience tõlkimisprobleemidele isikulugude uurimisel pühendab tähelepanu ka nt soome uurija Ulla-Maija Peltonen (2008): ta väidab, et ingliskeelses teaduskirjanduses kasutatav sõna experience on kohati tõlgitav "elamuse" (alati individuaalne ja emotsionaalne, tulenev üksikjuhtumist), kohati "kogemusena" (mis on elamuse mõistest laiem, olles ka abstraktne, protsessiline ja võib olla nii individuaalne kui ka kollektiivne).

14 Jutt on ajavahemikus 1984-1990 toimunud arheoloogilistest väljakaevamistest Maidlas. Maidla kalme hõlmab 2150 ruutmeetrit, olles Eesti suurim teadaolev kivikalme. Kalme on rajatud 5.-6. sajandil, uuesti kasutusele võetud 10. sajandil, eriti palju on kalmesse maetud 11.-12. sajandil ning 13. sajandi alguses. Kalmes on nii põletus- kui ka laibamatuseid (vt lähemalt Mandel 1993: 15; 40-41, fotosid leidudest ja kalmest 78-79). 
${ }^{15}$ Vt jutustamisolukorra mõju tekstile nt Anu Korb 2005: 73-109, Palmenfelt 2006 (välitöömeetodid ning koguja ja jutustaja koostöö); Pöysä 2006 (suulised ja kirjalikud eluloo- või tõsielu-teemajutud); Jaago 2006a: 481-488 (sama teema suulised ja kirjalikud esitused).

${ }^{16}$ Jälgides rahvaluuleõppurite lõputööde kaitsmisi 2009. aasta kevadel Tartu Ülikoolis tabasin järjekindlat oponentide (või endagi) märkusi stiilis: kas see või teine uurija väide (üldistus) tuli esile tekstidest endist (materjalist) või on selline tõdemus tekkinud siiski tulenevalt uurija tahtest. See viitab suundumusele eemalduda kontekstianalüüsi püüdlevas uurimuses tekstidest endist; või ka sellele, et teaduslikus esituses ei kasutata meetodit, mis veenaks teaduspublikut.

${ }^{17}$ Seda Leena Marander-Eklundi lähenemisviisi on Eestis rakendanud Kerttu Maripuu (2009).

${ }^{18}$ Vt märksõnu 'pärimuslik ajalugu' ja 'pärimusliku ajaloo uurimine' Jaago 2006b.

19 Vrd nt Aivar Jürgensoni (2008) käsitlust rahvuslike stereotüüpide ja poliitilise lojaalsuse kujunemise seotusest biograafiliste sündmustega.

${ }^{20}$ Eesti Kirjandusmuuseum, Eesti Rahvaluule Arhiiv, EKRK I 90, lk 95, 113-128.

${ }^{21}$ Tartu Ülikooli eesti ja võrdleva rahvaluule osakonnas asuv Tiiu Jaago kogutud pärimusliku ajaloo materjalikogu: MK - Läänemaa 2009, CD: Ainu Tikenberg, 1-A002 (27. 07. 2009).

${ }^{22}$ Linnalugude all pean antud juhul silmas olukorda, kui need rajanevad kindlal motiivil nagu vorstivabrikud (Kalmre 2007), valge laev (Tammela 2009): ühelt poolt on need küll traditsioonilised, ent aktualiseerudes teatud ajaloolises kontekstis, on need vältimatult ka ajastusidusad.

23 'Aegade kokkujooks' tähistab jutustamiste käigus tekkivat nähtust, kus tõsielus pikemale perioodile paigutuvad sündmused ja olukorrad, mis ajaloodokumentide abil on rekonstrueeritavad, toimuvad juttudes lühema perioodi jooksul (nt vaarvanemate elulood segunevad vanavanemate omadega).

${ }^{24}$ Ajaloolise jutu-uurimise selgitust vt täpsemalt nt Beyer 2003.

${ }^{25} \mathrm{Nt}$ erinevad allikad võivad samu asju kirjeldada näiteks kas nostalgia või iroonia võtmes, erinevaid sõnastusi kasutades (vrd "taganema" vs "jalga laskma"), ent kui uurija valib ainult ühe väljendusviisi neist, loobub ta uurijaomasest vaatleja-analüüsija vaatepunktist.

${ }^{26}$ Need on näited, kus oponendil tekib küsimus: kas see tuli materjalist välja, kas see vaatepunkt on materjalist enesest leitav.

\section{Arhiiviallikad}

EKRK - eesti kirjanduse ja rahvaluule kateedri kogu, asub Eesti Kirjandusmuuseumi Eesti Rahvaluule Arhiivis. 


\section{Kirjandus}

Andrews, Molly 2008. Never the last word: Revisiting data. Andrews, Molly \& Squire, Corinne \& Tamboukou, Maria (toim). Doing Narrative Research. Los Angeles \& London \& New Dehli \& Singapore: Sage, lk 86-101.

Apo, Satu 2003. Rahvapärase mõtteviisi uurimine arhiivi- ja küsitlusmaterjali abil. Jaago, Tiiu (koost). Pärimus ja tõlgendus. Artikleid folkloristika ja etnoloogia teooria, meetodite ning uurimispraktika alalt. Tartu: Tartu Ülikooli Kirjastus, lk 218-233.

Arukask, Madis 2000. Eksimine vadja ja setu rahvakultuuris ning folkloorse etteantuse osa selles. Kõiva; Mare (toim). Sator 2. Artikleid usundi- ja kombeloost. Tartu: Eesti Kirjandusmuuseum, lk 96-112.

Beyer, Jürgen 2000. Ilmutusjuttude teisenemisest Saksamaal ja Skandinaavia maades aastatel 1350-1700. Mäetagused 14, lk 62-82.

Beyer, Jürgen 2003. Ajalooline jutu-uurimine. Jaago, Tiiu (koost). Pärimus ja tõlgendus. Artikleid folkloristika ja etnoloogia teooria, meetodite ning uurimispraktika alalt. Tartu: Tartu Ülikooli Kirjastus, lk 81-93.

Ehin, Kristiina 2004. The Heritage of Estonian Folk Singer Kadri Kukk from Karksi Parish in the light of Feminist research: the Ache and Authority of One's Gender. Question and not only Answers. Feminist Folklore Research and the Interviews Conducted by Folklorists with Kadri Kukk from Point of View of an "Armchair Scientist". Leete, Art \& Valk, Ülo (toim). Studies in Folk Culture II. Peoples' Lives: Songs and Stories, Magic and Law. Tartu: Tartu University Press, lk 91-131.

Fingerroos, Outi \& Haanpää, Riina 2006. Muistitietotutkimuksen ydinkysymyksiä. Fingerroos Outi \& Haanpää, Riina \& Heimo, Anne \& Peltonen, Ulla-Maija (toim). Muistitietotutkimus. Metodologisia kysymyksiä. Helsinki: Suomalaisen Kirjallisuuden Seura, lk 25-48.

Hiiemäe, Mall 1978. Kodavere pajatused. Kujunemine ja koht rahvajututraditsioonis. Tallinn: Eesti Raamat.

Honko, Lauri 1980. Miten luoda terminologia haltijaperinteen tutkimukselle? Lehtipuro, Outi (toim). Perinteentutkimuksen perusteita. Porvoo \& Helsinki \& Juva: Werner Söderström OY, lk 77-129.

Jaago, Tiiu 1995. Suulise traditsiooni eripära vaimses kultuuris. Perepärimuse põhjal. Pro Ethnologia 3. Tartu: Eesti Rahva Muuseum, lk 116-121.

Jaago, Tiiu 2006a. Critical events of the 1940s in Estonian life histories. Sign Systems Studies 34 (2). Taverna, Licia \& Montes, Stefano (toim). Special issue: Between semiotics and anthropology: Life histories and other methodological issues, lk 471-492.

Jaago, Tiiu 2006b. Pärimuslik ajalugu/ Pärimusliku ajaloo uurimine. Jaago, Tiiu (koost ja toim). Argikultuuri uurimise terminoloogia e-sõnastik. Tartu Ülikool, eesti ja võrdleva rahvaluule osakond (http://argikultuur.e-uni.ee - 28. oktoober 2009). 
Jaago, Tiiu 2007 [2001]. Perepärimus folkloristika vaateväljas. Kõiva, Mare (toim). Sator 6. Artikleid usundi- ja kombeloost. Tartu: Eesti Kirjandusmuuseumi Teaduskirjastus, lk 230-251.

Jaago, Tiiu 2009. Valge hobuse kivi lugu. Üdrumal 22. veebruaril 1918. aastal toimunud lahing pärimusliku ajaloo vaatevinklist. Paras, Ülla (toim). Läänemaa Muuseumi toimetised XII. Haapsalu: Läänemaa Muuseum, lk 116-144.

Jürgenson, Aivar 2008. Pronkssõduri sammude vaibuvas kajas. Siberist remigreerunud eestlaste kohanemisest Eestis: keel, stereotüübid, elulugu. Mäetagused 38, lk 75100 (http://www.folklore.ee/tagused/nr38/jyrgenson.pdf - 28. oktoober 2009).

Kalda, Mare 2006. Mõisakingsepa isikukogemuse lugu. Rõngu kirikuraamatus ja muistendikogumikes. Mäetagused 35, lk 95-114 (http://www.folklore.ee/tagused/nr35/ kalda.pdf - 28. oktoober 2009).

Kalkun, Andreas 2004. Anne Vabarna nina. Tõest ja valest seto naise autobiograafilistes lauludes. Sarv, Mari (toim). Regilaul - loodud või saadud? Tartu: Eesti Kirjandusmuuseum, lk 29-49.

Kallas, Triin 2007. Olemus või konstruktsioon. Vikerkaar 4-5, lk 166-174.

Kalmre, Eda 2007. Hirm ja võõraviha sõjajärgses Tartus. Pärimuslooline uurimus kannibalistlikest kuulujuttudest. Tänapäeva folkloorist 7. Tartu: EKM Teaduskirjastus.

Knuuttila, Seppo 1994: Tyhmän kansan teoria. Näkökulmia menneestä tulevaan. Tietolipas 129. Helsinki: Suomalaisen Kirjallisuuden Seura.

Korb, Anu 2005. Venemaal rahvuskaaslasi küsitlemas: folkloristliku välitöö metoodilisi aspekte. Studia Ethnologica et Folkloristica Tartuensia 9. Tartu: Tartu Ülikooli Kirjastus.

Krikmann, Arvo 2001. Viimane pikk pilk "Proverbia Septentrionalia" valmimisloole. Paar sammukest XVIII. Eesti Kirjandusmuuseumi aastaraamat. Tartu: Eesti Kirjandusmuuseum, lk 11-114.

Laagus, Aino 1973. Situatsioonianalüüsist folkloristikas. Keel ja Kirjandus 7, lk 404412 .

Laugaste, Eduard 1962. Eesti regivärsi struktuuriküsimusi. Tartu Riikliku Ülikooli toimetised 117. Tartu: Tartu Riiklik Ülikool, lk 25-70.

Loorits, Oskar 1998 [1927]. Liivi rahva usund II. Tartu: Eesti Keele Instituudi rahvausundi töörühm.

Lotman, Juri 1991. Kultuurisemiootika. Tekst - kirjandus - kultuur. Tallinn: Olion.

Mandel, Mati 1993. Läänemaa esiajalugu. Haapsalu: Lääne Elu.

Marander-Eklund, Lena 2006. The Actors in Young Women's Childbirth Narratives. Kaivola-Bregenhøj, Anikki \& Klein, Barbo \& Palmenfelt, Ulf (toim). Narrating, Doing, Experiencing. Nordic Folkloristic Perspectives. Studia Fennica: Folkloristica 16. Helsinki: Finnish Literature Society, lk140-157.

Maripuu, Kerttu 2009. Meeste jutud sünnitusest: mees- ja jutu-uurimuslikust aspektist. Bakalaureusetöö. Käsikiri Tartu Ülikooli eesti ja võrdleva rahvaluule osakonnas. 
Nekljudov, Sergei 1998 = Неклюдов, Сергей 1998. Исторический нарратив: между реальной действительностью и фольклорно-мифологической схемой. Вогданов, Константин \& Панченко, Александр (toim). Мифология и повседневность. Санкт-Петербург: Институт русской литературы (Пушкинский Дом) Российской Академии Наук, lk 288-292.

Nekljudov, Sergei 2003. Vene rahvaluuleteadus ja strukturaalsemiootilised uurimused. Jaago, Tiiu (koost). Pärimus ja tõlgendus. Artikleid folkloristika ja etnoloogia teooria, meetodite ning uurimispraktika alalt. Tartu: Tartu Ülikooli Kirjastus, lk 26-36.

Oras, Janika 2008. Viie 20. sajandi naise regilaulumaailm. Arhiivitekstid, kogemused ja mälestused. Eesti Rahvaluule Arhiivi toimetused 27. Tartu: Eesti Kirjandusmuuseumi Teaduskirjastus.

Palmenfelt, Ulf 2006. The Dark Shadow of the Un-mentioned Event. Collapsing Talewords and Narrative Reparation. Kaivola-Bregenhøj, Anikki \& Klein, Barbo \& Palmenfelt, Ulf (toim). Narrating, Doing, Experiencing. Nordic Folkloristic Perspectives. Studia Fennica: Folkloristica 16. Helsinki: Finnish Literature Society, lk 101-116.

Patterson, Wendy 2008. Narratives of events: Labovian narrative analysis and its limitations. Andrews, Molly \& Squire, Corinne \& Tamboukou, Maria (toim). Doing Narrative research. Los Angeles \& London \& New Dehli \& Singapore: Sage, lk 22-40.

Peltonen, Ulla-Maija 2008. Boundless experience. Tartu Ülikoolis 30. 10. 2008 peetud loengu videosalvestus: (http://193.40.32.5/Producer/2008/rahvaluule/03_Peltonen/ - 29. oktoober 2009).

Phoenix, Ann 2008. Analysing narrative contexts. Andrews, Molly \& Squire, Corinne \& Tamboukou, Maria (toim). Doing Narrative Research. Los Angeles \& London \& New Dehli \& Singapore: Sage, lk 64-77.

Portelli, Alessandro 1997. The Battle of Valle Giulia: Oral History and the Art of Dialogue. Madison: University of Wisconsin Press.

Portelli, Alessandro 2000 [1991]. What makes oral history different. Perks, Robert \& Thompson, Alistair (toim). The Oral History reader. London \& New York: Routledge, lk 63-74.

Pöysä, Jyrki 2006. Kilpakirjoitukset muistitietotutkimuksessa. Fingerroos, Outi \& Haanpää, Riina \& Heimo, Anne \& Peltonen, Ulla-Maija. Muistitietotutkimus. Metodologisia kysymyksiä. Helsinki: Suomalaisen Kirjallisuuden Seura, lk 221-244.

Stahl, Sandra K. D. [a-ta]. Jutud isiklikest kogemustest. VTK raamat (http:// www.folklore.ee/seminar/ - 29. oktoober 2009). [Tõlgitud: Stahl, Sandra K. D. 1986 [1983]. Personal Experience Stories. Dorson, Richard M. (toim). Handbook of American Folklore. Bloomington, Indiana University Press, lk 268-276.]

Tammela, Hiljar 2009. Millest läänlane mõtles ja rääkis 1944-1950: Kommunistliku Partei raportid elanikkonna meeleoludest ajalooallikana. Paras, Ülla (toim). Läänemaa Muuseumi toimetised XII. Haapsalu: Läänemaa Muuseum, lk 145-161.

Tedre, Ülo 1964. Tähelepanekuid regivärsilise rahvalaulu tüpoloogiast. Pino, Veera \& Tedre, Ülo \& Viidalepp, Richard (toim). Eesti rahvaluulest. Tallinn: Eesti NSV Teaduste Akadeemia, Keele ja Kirjanduse Instituut, lk 7-33. 
Tonkin, Elizabeth 1999 [1992]. Narrating our pasts: the social construction of oral history. Cambridge Studies in Oral and Literate Culture 22. Cambridge: Cambridge University Press.

Voolaid, Kalle 2001. Jõumehe fenomen. Georg Lurich ajaloolisest tegelasest rahvajutu kangelaseks. Jaago, Tiiu (koost). Pärimuslik ajalugu. Tartu:Tartu Ülikooli Kirjastus, lk 183-201.

\section{Summary}

\section{The Story and Event in Narrative Research: From Situation Analysis to Context Analysis}

\section{In commemoration of Aino Laagus (1944-2004)}

Tiiu Jaago

Key words: narrative research methods, oral narrative history, situation analysis

The article discusses a development tendency in narrative research, focuses on the situation analysis worked out by Aino Laagus in the early 1970s, and introduces the boundaries of structuralism and constructivism in the study of true life stories during the past forty years. Leaving aside the distribution of themes and motifs and genre research methods, the article poses two main questions: (i) what is the situation analysis method and (ii) how can it be applied in contemporary context-centred narrative research. The article primarily demonstrates the relationships between situation analysis and the study of life history and (oral) narrative history. 